University of Nebraska - Lincoln

DigitalCommons@University of Nebraska - Lincoln

Faculty Publications from the Harold W. Manter Laboratory of Parasitology

8-2003

\title{
Neohaematotrephus arayae n. sp. (Digenea: Echinostomiformes: Cyclocoelidae) in Jacana spinosa (Aves: Charadriiformes: Jacanidae) from the Área de Conservación Guanacaste, Costa Rica
}

\author{
David Zamparo \\ University of Toronto \\ Daniel R. Brooks \\ University of Toronto,dnlbrooks@gmail.com \\ Douglas Causey \\ University of Alaska Anchorage, dcausey@uaa.alaska.edu \\ Beatriz Rodriguez \\ Universidad de Costa Rica
}

Follow this and additional works at: https://digitalcommons.unl.edu/parasitologyfacpubs

Part of the Parasitology Commons

Zamparo, David; Brooks, Daniel R.; Causey, Douglas; and Rodriguez, Beatriz, "Neohaematotrephus arayae n. sp. (Digenea: Echinostomiformes: Cyclocoelidae) in Jacana spinosa (Aves: Charadriiformes: Jacanidae) from the Área de Conservación Guanacaste, Costa Rica" (2003). Faculty Publications from the Harold W. Manter Laboratory of Parasitology. 256.

https://digitalcommons.unl.edu/parasitologyfacpubs/256

This Article is brought to you for free and open access by the Parasitology, Harold W. Manter Laboratory of at DigitalCommons@University of Nebraska - Lincoln. It has been accepted for inclusion in Faculty Publications from the Harold W. Manter Laboratory of Parasitology by an authorized administrator of DigitalCommons@University of Nebraska - Lincoln. 


\title{
NEOHAEMATOTREPHUS ARAYAE N. SP. (DIGENEA: ECHINOSTOMIFORMES: CYCLOCOELIDAE) IN JACANA SPINOSA (AVES: CHARADRIIFORMES: JACANIDAE) FROM THE AREA DE CONSERVACIÓN GUANACASTE, COSTA RICA
}

\author{
David Zamparo, Daniel R. Brooks, Douglas Causey*, and Beatriz Rodriguez $†$ \\ Department of Zoology, University of Toronto, Toronto, Ontario M5S 3G5, Canada. e-mail: zamparo@zoo.utoronto.ca
}

\begin{abstract}
Specimens of a species of cyclocoelid digenean inhabiting Jacana spinosa from the Area de Conservación Guanacaste, Costa Rica, most closely resemble Haematotrephus facioi (Brenes and Arroyo, 1962) Yamaguti, 1971, in the same host from Aranjuez, Puntarenas Province, Costa Rica, in having confluent vitelline follicles posteriorly, diagnostic of Neohaematotrophus, and in pharynx length, ovary width, and cirrus sac on the sinistral side. The new species is also highly similar in appearance to $H$. gendrei Dubois, 1959, also inhabiting a jacanid (from West Africa), which has vitelline follicles confluent posteriorly, and extending anteriorly to the intestinal bifurcation and genital pore opening immediately posterior to the anterior margin of the pharynx. Like $H$. facioi, $H$. gendrei has a relatively much shorter and broader cirrus sac than does the new species. Examination of the holotype and paratype of $\mathrm{H}$. facioi confirmed that the specimens from Guanacaste differ in having a longer body, a larger ovary and eggs, and smaller testes. They also have the ovary on the sinistral rather than the dextral side of the body, genital pore anterior to the pharynx rather than at or posterior to the level of the posterior margin of the pharynx, longer and thinner cirrus sac, and eggs without eyespotted miracidia. Half the eggs in both specimens of $H$. facioi have well-developed eyespotted miracidia, whereas the typical condition for cyclocoelids is for virtually all eggs to exhibit eyespotted miracidia. Both $H$. facio and $H$. gendrei are transferred to Neohaematotrophus, along with the new species.
\end{abstract}

The family Cyclocoelidae represents an enigmatic group of digeneans living as adults primarily in the body cavities and air sacs of birds, although there have been reports of their being found in the trachea (Pence and Bush, 1973; Scott et al., 1981), orbits, and nasal cavities (Taft and Heard, 1978). Migration from the intestine to the air sacs is known to involve a bodycavity route (Scott et al., 1982; McLaughlin and Marcogliese, 1983). When miracidia hatch, they already contain redia. Rediae have posterior appendages, and some also have anterior appendages. The miracidium is either ingested or actively seeks the intermediate host, but it is the redia that penetrates aquatic snails, both marine and freshwater (Taft and Heard, 1978). Cercariae are produced within this single redia; no other generation of rediae is produced. Cercariae are tailless and either encyst within the redia (Stunkard, 1934; Johnston and Simpson, 1940; Wooton, 1964; McLaughlin, 1976) or emerge and encyst in the host's tissues (Timon-David, 1955). Infection of the definitive host requires active foraging on the infected snails.

In this report on the activities of an inventory of the eukaryotic parasites of vertebrates living within the Area de Conservación Guanacaste (http://www.acguanacaste.ac.cr) in northwestern Costa Rica (http://brooksweb.zoo.utoronto.ca/index.html), we describe a new species of cyclocoelid digenean inhabiting Jacana spinosa.

\section{MATERIALS AND METHODS}

Worms were collected alive from recently killed birds, killed and fixed by shaking in hot formalin, then stored in $70 \%$ ethanol. Specimens were stained with Mayer's hematoxylin, dehydrated, and mounted in Canada balsam. All measurements are in micrometers unless otherwise stated; mean values are followed by actual values in parentheses. All figures were made by using a drawing tube.

Received 9 October 2002; revised 5 March 2003; accepted 5 March 2003.

* Museum of Comparative Zoology, Harvard University, Cambridge, Massachusetts.

$\dagger$ Escuela de Microbiologia, Universidad de Costa Rica, San Pedro, Costa Rica.

\section{DESCRIPTION}

\section{Neohaematotrephus arayae $\mathbf{n . ~ s p . ~}$} (Figs. 1-3)

Description (based on 3 mature worms): Total body length: $9.2 \mathrm{~mm}$ $(8.8,9.60,9.2 \mathrm{~mm})$. Maximum body width $2.5 \mathrm{~mm}(2.4,2.7,2.5 \mathrm{~mm})$ occurring equatorially. Ventral sucker lacking. Oral sucker subterminal, poorly developed, $268(253,281,270)$ wide. Pharynx, large, round, very muscular, $253(266,247,247)$ long by $271(266,266,281)$ wide. Prepharynx short, $108(76,114,133)$, outer wall covered by small gland cells. Esophagus typically c shaped, expanded in middle, narrowing at junction with pharynx and with ceca, lined with epithelial cells, 377 $(334,360,436)$ long by $105(82,87,146)$ wide. Ceca forming cyclocoel. Genital pore ventral to anterior margin of pharynx. Testes obliquely situated, oval, sinistral testis $258(255,266,255)$ long by $228(255$, $220,209)$ wide. Dextral testis anterior to sinistral testis and slightly smaller, $222(190,228,247)$ long by $200(201,209,190)$ wide. Cirrus sac elongated, weakly muscled, thin walled, $633(642,668,591)$ long by $77(77,92,62)$ wide, containing unarmed cirrus, pars prostatica, and internal seminal vesicle. Ovary oval, anterior to testes on sinistral side, $246(254,256,228)$ long by $224(255,209,209)$ wide. Mehlis gland posterodorsal to ovary, may partially overlap ovarian margins ( 2 of 3 specimens). Laurer canal arising dorsally from distal portion of ootype, ending blindly, filled with vitelline material and possibly other waste products of egg production. Uterus passing posteroventral from ootype, initial portion glandular, possibly serving as receptaculum seminis uterinum; loops then ascending anteriad and ventral to ceca; some uterine branches extending extracecally in midbody. Vitellarium follicular, lateral, confluent posteriorly near outer wall of cyclocoel; follicles 74-101 in diameter. Vitelline reservoir posterodorsal to ootype, entering distal portion of ootype near Laurer canal. Metraterm present, thick walled and expanded distally, lined with gland cells. Eggs elliptical, yellow to light brown in color, eggs near metraterm, 147 (133-160) long by 88 (84-99) wide, none possessing miracidia with eyespots. Excretory pore terminal, vesicle expanded posterior to cyclocoel.

\section{Taxonomic summary}

Type host: Jacana spinosa (Aves: Charadriiformes: Jacanidae). Site of infection: Body cavity.

Type locality: Laguna Los Jicaros, Sector Santa Elena $\left(10^{\circ} 52^{\prime} 1^{\prime \prime} \mathrm{N}\right.$, $85^{\circ} 38^{\prime} 35^{\prime \prime} \mathrm{W} ; 321 \mathrm{~m}$ elevation).

Type specimens: Holotype, USNPC no. 93196; paratypes, USNPC no. 93197.

Etymology: The species is named after Sra. Elda Araya, Area de Conservación Guanacaste (ACG) parataxonomist, in recognition of her outstanding efforts with the parasite inventory. 

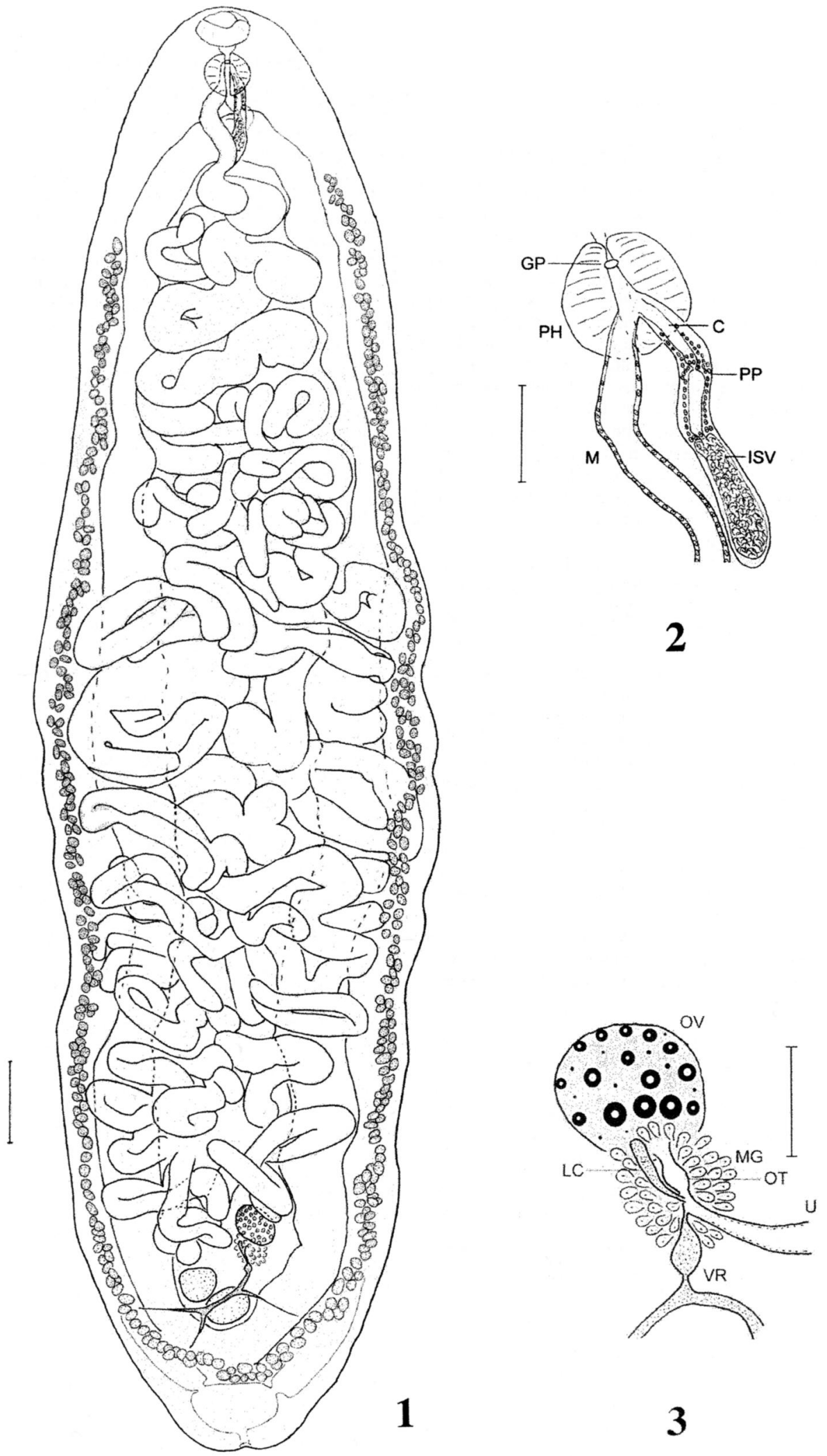

FIGURES 1-3. Haematotrephus arayae n. sp. 1. Ventral view of holotype. Bar $=500 \mu \mathrm{m}$. 2. Male genitalia: C, cirrus; GP, genital pore; ISV, internal seminal vesicle; M, metraterm; PH, pharynx; PP, pars prostatica. Bar $=200 \mu \mathrm{m}$. 3. Female reproductive system: LC, Laurer canal; MG, Mehlis gland; OT, ootype; OV, ovary; VR, vitelline reservoir; U, uterus. Bar $=200 \mu \mathrm{m}$. 


\section{Remarks}

According to Kanev et al.'s (2002) recent key to the Cyclocoelidae, the new species is a member of the subfamily Haematotrephinae Stossich, 1902, by virtue of having a pretesticular ovary. Furthermore, by virtue of its having confluent vitelline follicles at the posterior end of the body and prepharyngeal genital pores, the new species belongs to Neohaematotrephus Kanev et al., 2002.

Among species placed in Neohaematotrephus by Kanev et al. (2002), the new species is most similar in appearance to Cyclocoelum (Haematotrephus) gendrei Dubois, 1959 in a jacanid from West Africa (French Guinea) (Dubois, 1959), which has vitelline follicles confluent posteriorly, vitelline follicles extending anteriorly to the intestinal bifurcation, and genital pores opening immediately posterior to the anterior margin of the pharynx. By having confluent vitelline follicles posteriorly, sinistral cirrus sac, and similar pharyngeal length and ovarian width, the new species most closely resembles C. (Haematotrephus) facioi Brenes and Arroyo, 1962, on the basis of 2 specimens in $J$. spinosa from Aranjuez, Puntarenas Province (Brenes and Arroyo, 1962). We examined the holotype and paratype of $C$. (H.) facioi and confirmed that the new species differs from it in some characters that might be affected by small sample size ( 2 for $C$. (H.) facioi vs. 3 for $N$. arayae): longer bodies, larger ovaries and eggs, and smaller testes. However, they also differ in more qualitative traits: $N$. arayae has the ovary on the sinistral rather than the dextral side of the body, genital pores anterior to the pharynx rather than at or posterior to the level of the posterior margin of the pharynx, longer and thinner cirrus sacs, and eggs without eyespotted miracidia. Half the eggs in both specimens of $C$. $(H$.) facioi have well-developed eyespotted miracidia, whereas the typical condition for cyclocoelids is for virtually all eggs to exhibit eyespotted miracidia. Like $C$. $(H$.) gendreii, $C$. $(H$.) facioi has a relatively much shorter and broader cirrus sac than does $N$. arayae.

Using primarily characters associated with the uterine loops, Yamaguti (1971) raised Haematotrephus to the generic level and placed $C$. (H.) facioi within it as H. facioi (Brenes and Arroyo, 1962) Yamaguti, 1971. Yamaguti (1971) also transferred $C$. $(H$.) gendreii to Corpopyrum Wittenberg, 1923 as C. gendrei (Dubois, 1959) Yamaguti, 1971. Using the recent key to cyclocoelid genera by Kanev et al. (2002), we place $H$. gendrei in Neohaematotrephus as N. gendrei (Dubois, 1959) comb. $\mathrm{n}$. and $H$. facioi on account of the difference in the position of the genital pores (prepharyngeal vs. postpharyngeal), in Uvitellina as $U$. facioi (Brenes and Arroyo, 1962) comb. $\mathrm{n}$. We hasten to add that we are not completely satisfied that 2 species occurring in the same host species in adjacent provinces of the same country should be placed in different genera in the absence of a phylogenetic analysis of cyclocoelids supporting such a placement.

\section{DISCUSSION}

The female reproductive system may be a source of phylogenetically informative characters (Zamparo and Brooks, 2003). Nonetheless, many descriptions of cyclocoelids lack detailed information about the female reproductive system. The most extensive discussion to date was made by Madhavi and Rao (1979), who in a study of Cyclocoelium elongatum reported a receptaculum seminis uterinum as well as a blindly ending Laurer canal containing vitelline material (and possibly sperm) arising near the insertion of the vitelline duct in the portion of the ootype proximal to the ovary. This condition of the Laurer canal has evolved at least 1 other time, among members of the Hemiuridae, where it is called the Juel organ (Gibson and Bray, 1979). All 3 specimens of $H$. arayae exhibit the configuration reported by Madhavi and Rao, with 1 exception. The vitelline reservoir and Laurer canal in $H$. arayae and in $H$. facioi enter the ootype distally rather than proximally (see Fig. 3). We note that the blindly ending Laurer canal may be confused with a portion of the vitelline duct because it may be packed with vitelline material.

\section{ACKNOWLEDGMENTS}

We are grateful to the scientific and technical staff of the ACG for supporting this study, in particular Elda Araya, Roger Blanco, Carolina Cano, Maria Marta Chavarría, Felipe Chavarría, Roberto Espinoza, Dunia Garcia, Guillermo Jimenez, Elba Lopez, Sigifredo Marin, Alejandro Masis, Calixto Moraga, Fredy Quesada, and Petrona Rios. We also thank Dan Janzen and Winnie Hallwachs, scientific advisers to the ACG, for their support. Host specimens were collected by D.C., Jeremiah Trimble (MCZ), and Calixto Moraga (ACG) under the authority of CITES Permit US9258251, CITES Permit CR9123440, Costa Rica Ministero del Ambiente y Energia Licencia 203640283 and Resoluciones 215-2001-OFAU and 411-2001-OFAU, Harvard University IACUC Protocol 21-09, and USDA APHIS Permit 47956 (form VS166A). Host necropsy and parasite collections were made by D.R.B., D.C., Elda Araya, Sara Brant, Marie Causey, Ben Hanelt, Calixto Moraga, and Petrona Rios. This study was funded by a research grant from the Natural Sciences and Engineering Research Council of Canada to D.R.B. and by a grant from the MCZ Putnam Expedition Fund to D.C.

\section{LITERATURE CITED}

Brenes, R., AND G. Arroyo. 1962. Helmintos de la republica de Costa Rica XX. Algunas trematodos de aves silvestres. Revista de Biologia Tropical 10: 205-227.

DuboIs, G. 1959. Revision des Cyclocoelidae Kossack 1911 (Trematoda). Revue Suisse de Zoologie 66: 67-147.

Gibson, D. I., AND R. A. Bray. 1979. The Hemiuroidea: Terminology, systematics and evolution. Bulletin of the British Museum (Natural History) Zoology 36: 35-146.

Johnston, T., AND E. Simpson. 1940. The anatomy and life history of the trematode, Cyclocoelum jaenschi $\mathrm{n}$. sp. Transactions of the Royal Society of South Australia 64: 273-278.

Kanev, I., V. Radev, And B. Fried. 2002. Family Cyclocoelidae Stossich, 1902. In Keys to the Trematoda, vol. 1, D. I. Gibson, A. Jones, and R. A. Bray (eds.). CAB International and The Natural History Museum, London, U.K., p. 135-145.

MADHAVI, R., AND K. H. RAO. 1979. Anatomy of female reproductive system of Cyclocoelium elongatum Harrah, 1921 (Trematoda: $\mathrm{Cy}-$ clocoelidae). Indian Journal of Parasitology 3: 139-142.

McLaughlin, J. 1976. Experimental studies on the life cycle of Cyclocoelum mutabile (Zeder) (Trematoda: Cyclocoelidae). Canadian Journal of Zoology 54: 48-54.

$\longrightarrow$, AND D. MARCOGLIESE. 1983. The migration, growth and development of Cyclocoelum occuleum (Kossack, 1911) (Trematoda: Cyclocoelidae) in Fulica americana (Gm.). Parasitology 87: 239_ 247.

Pence, D., And A. Bush. 1973. Polycyclorchis eudocimi gen et sp. n. (Trematoda: Cyclocoelidae) from the trachea of the white ibis, $E u-$ docimus albus L. Journal of Parasitology 59: 85-89.

ScotT, M., J. Mclaughlin, and M. Rau. 1981. Experimental studies on the taxonomic relationships in the subfamily Typhlocoelinae (Digenea: Cyclocoelidae). Systematic Parasitology 3: 129-143.

- M. Rau, and J. McLaughlin. 1982. Comparative migration, growth and development of Typhlocoelum cucumerinum sisowi dabbling ducks and Typhlocoelum cucumerinum cucumerinum in diving ducks. Parasitology 84: 333-350.

StUNKARD, H. 1934. The life history of Typhlocoelum cymbium (Diesing, 1850) Kossack, 1911 (Trematoda, Cyclocoelidae) a contribution to the phylogeny of the monostomes. Bulletin de la Société Zoologique (France) 5: 447-466.

TAFT, S., AND R. HEARD. 1978. Aspects of the larval development of Ophthalmophagus sp. (Trematoda: Cyclocoelidae). Journal of Parasitology 64: 597-600.

Timon-David, J. 1955. Cycle évolutif d'un trématode cyclocoelidé: Pseudhyptiasmus dollfusi Timon-David 1950 récherches experimentales. Annales de Parasitologie 30: 43-61.

Wooton, D. 1964. Comparative studies on the life cycle of two cyclocoeliids (Cyclocoelidae: Trematoda). Proceedings of the First International Congress of Parasitology 1: 524-525.

YAMAGUTI, S. 1971. Synopsis of the digenetic trematodes of vertebrates. Keigaku Publishing Company, Tokyo, Japan, 1074 p.

Zamparo, D., AND D. R. BROOKS. 2003. Phylogenetic systematic assessment of the Aspidobothrea (Platyhelminthes, Neodermata, Trematoda). Zoologica Scripta 32: 83-93. 